\title{
Assessing The Commitment of Indonesian Government Towards Climate Change Policy: The Yudhoyono Presidency 2004-2014 Menilai Komitmen Pemerintah Indonesia terhadap Kebijakan Perubahan Iklim: Pemerintahan Presiden Yudhoyono 2004-2014
}

\section{Lidya Christin Sinaga}

Lembaga Ilmu Pengetahuan Indonesia

email: lidya.bosua@gmail.com

\begin{tabular}{l}
\hline Riwayat Artikel \\
\hline Diterima: 1 Juli 2020 \\
Direvisi: 1 Oktober 2020 \\
Disetujui: 5 Oktober 2020 \\
doi: 10.22212 jp.v11i2.1752
\end{tabular}

\section{Abstract}

As the largest archipelagic state and the world's third-largest emitter of greenhouse gases, Indonesia's commitment to climate change policy is critical. In 2009, Indonesia under President Susilo Bambang Yudhoyono showed its commitment by setting environmental targets, which included a commitment to reduce deforestation by decreasing the number of forest fires by 20 percent each year. The commitment, however, could not be fully realised. Unsurprisingly, in 2015 for the umpteenth time, a thick haze of smog caused by the forest fires blanketed Indonesia and its neighbours, Malaysia and Singapore. The pollution unavoidably raises uncertainty of Indonesia's role in advancing the climate change regime. Since 85 percent of emissions in Indonesia come from deforestation, Indonesia's failure to tackle this problem is a serious issue in relation to its international role. Indonesia's international commitment and motivation then come into questions, particularly considering the country's domestic conduct. While not dismissing the positive impacts of its active commitment, this paper evaluates climate change policy in Indonesia during the Yudhoyono administration by applying the context of multi-level governance, namely the impact of international, local government, and non-governmental actors in environmental policy. None should be in any doubt on the point that Yudhoyono has dealt with climate change issues more seriously than any previous president. However, since Indonesia falls behind on its national commitment, this paper argues that Indonesia's role in establishing climate change regime is more driven by its international stature.

Keywords: Climate Change Policy; Indonesia; Yudhoyono Presidency; Multilevel Governance; Deforestation. 


\begin{abstract}
Abstrak
Sebagai negara kepulauan terbesar dan penghasil emisi gas rumah kaca terbesar ketiga di dunia, komitmen Indonesia terhadap kebijakan perubahan iklim sangat penting. Pada tahun 2009, Indonesia di bawah Presiden Susilo Bambang Yudhoyono menunjukkan komitmennya dengan menetapkan target untuk mengurangi deforestasi dengan mengurangi jumlah kebakaran hutan sebesar 20 persen setiap tahun. Namun, target ini tidak sepenuhnya dapat diwujudkan. Pada tahun 2015 untuk yang kesekian kalinya, kabut asap tebal yang disebabkan oleh kebakaran hutan menyelimuti Indonesia dan tetangganya, Malaysia dan Singapura. Kasus ini menimbulkan ketidakpastian atas peran Indonesia dalam memajukan rezim perubahan iklim. Mengingat 85 persen emisi di Indonesia berasal dari deforestasi, kegagalan Indonesia untuk mengatasi masalah ini adalah persoalan serius terkait peran internasionalnya, apalagi dengan melihat implementasi pada tataran domestiknya. Meskipun tidak menampik dampak positif dari komitmen aktifnya, tulisan ini mengevaluasi kebijakan perubahan iklim di Indonesia selama masa kepresidenan Yudhoyono dengan menerapkan konteks tata kelola multi-level, yaitu dampak aktor internasional, pemerintah daerah, dan non-pemerintah dalam kebijakan lingkungan. Seharusnya tidak ada yang meragukan bahwa Yudhoyono telah menangani masalah perubahan iklim dengan lebih serius daripada presiden sebelumnya. Namun, melihat minimnya komitmen dan implementasi di tingkat nasional, peran Indonesia dalam membangun rezim perubahan iklim lebih tampak sebagai upaya membangun citra internasional.

Kata kunci: Kebijakan Perubahan Iklim; Indonesia; Kepresidenan Yudhoyono; Tata Kelola Multi-level; Deforestasi.
\end{abstract}

\section{Introduction}

As the largest archipelagic state and the world's third largest emitter of greenhouse gases, ${ }^{1}$ Indonesia is very vulnerable to climate change impacts. The impacts are so massive, such as temperature increases, sea level rise, changes of rainfall pattern and disaster especially droughts and floods. ${ }^{2}$ In regards to these impacts, Indonesia took a leading role on climate change at the international level. Indonesia was considered to be a country that has strong commitment to address

1 World Resources Institute, "Forest and Landscapes in Indonesia", undated, accessed on 4 June 2020. $<$ http://www.wri.org/our-work/project/forests-andlandscapes-indonesia/climate-change-indonesia >

2 R. Oktaviani, S. Amaliah, C. Ringler, MW Rosegrant, TB Sulser, "The Impact of Global Climate Change on the Indonesian Economy", IFPRI Discussion Paper 01148, 2011, accessed on 4 June 2020, <http://www.ifpri.org/sites/default/files/ publications/ifpridp01148.pdf $>$ climate change. ${ }^{3}$ Indonesia ratified United Nations Framework Convention on Climate Change (UNFCCC) in 1994 and continued its commitment by signed the Kyoto Protocol in 2004. Following this, in 2009 G-20 meeting, President Susilo Bambang Yudhoyono (SBY) signed the commitment to reduce greenhouse gas (GHG) emissions by $26 \%$ (by Business as Usual/BAU) - $41 \%$ (by international support) in 2020.

By using the case of Indonesia's commitment in 2009 G-20 meeting, none should be in any doubt on the point that Yudhoyono has dealt with climate change issue more seriously than any previous president. When Indonesia put

3 F. Ardiansyah, N. Gunningham, P. Drahos, "Climate Change and Energy Security Post-Cancun: The Indonesia Perspective", in NA, Putra, E. Han, Governments' Responses to Climate Change: Selected Examples From Asia Pacific (Singapore: Springer, 2014), pp. 55-80. 
its commitment of reducing emissions by as much as 41 percent in this meeting, no one can argue that Indonesia has a strong commitment on climate change mitigation. Although G20 summit is not aimed to specifically address climate change issue, however as argued by Chung, a gridlock in the climate change negotiations led by the United Nations (UN) has recently shifted the negotiation process to new groups and institutions outside the UN, such as the G20. ${ }^{4}$ Therefore, the commitment of Indonesia in this meeting was considered as an important milestone for climate change regime since Indonesia is the first non-Annex 1 countries which voluntarily committed to reduce its emissions. Yudhoyono's special mention on aspirations of developing and underdeveloped countries in his statement seems to confirm the desire of Indonesia to be a voice of this group.

However, proactive international commitment was not accompanied by domestic improvement. After 5 years signing this commitment, the rate of deforestation was precisely increasing. The new elected President in 2014, Joko Widodo (Jokowi), was hoped to bring a new commitment towards environment degradation, especially towards climate change impacts. It was actively endorsed by environmental pressure groups in Indonesia during and after election. Jokowi's policy to dissolve National Board on Climate Change and National Agency on Reducing Emissions from Deforestation and Forest Degradation $(\mathrm{REDD}+)$, and put its function under Ministry of Environment in 2015, led into

4 S. Happaerts, H. Bruyninckx, "Rising Powers in Global Climate Governance. Negotiating in the New World Order", Working Paper No. 124, 2013, accessed on 4 June 2020, <https://ghum.kuleuven. be/ggs/publications/working_papers/new_series/ wp121-130/wp124-happaerts-bruyninckx-finaal. pdf $>$ debate regards to Jokowi's commitment to climate change policy.

Regarding the policy dynamics between these governments, therefore, this essay lays out how the commitment of government and the multi-level governance, such as international actors, local government, and non-governmental actors, influence the state capacity in dealing with climate change policy in Indonesia, especially since it ratified the Kyoto Protocol in 2004 during Yudhoyono presidency. However, since the national commitment left behind, this paper argues that the Yudhoyono presidency left Indonesia's role in establishing climate change regime is more driven by its international stature. This paper is divided into five parts. First, it presents the Yudhoyono presidency's climate change policy since he came into power in 2004. Then, it assesses the context of multi-level governance in climate change policy in Indonesia, namely the impacts of international actors, local government, and non-governmental actors. The next part is evaluating climate change policy in Indonesia. Furthermore, it assesses Indonesian commitment on emission reduction target in 2009 by looking through the actors and their motivation. Lastly, before concluding, it explains the extent to which the national commitment in regards to climate change policy left behind.

\section{The Yudhoyono Presidency and Climate Change Policy}

The 1998 political reform was the turning point for Indonesian political system. After 32 years in authoritarian regime under Soeharto, Indonesia entered a new democratic political system. Indonesia then enjoyed a multiparty system with its first democratic election in 1999. The amendment of the 1945 constitution enabled 
free press, free of assembly and associate (article 28). The new circumstances then encouraged a more open political climate which give the opportunity for non-state actors to promote human security-related issues, such as environment.

The more stable domestic conditions in 2004, both politics and economics, has pushed Indonesia to reinvolve in foreign policy related to environment, that has been left out during domestic crisis since 1998. Indonesia under Megawati Soekarnoputri started by ratifying Kyoto Protocol in June 2004. A few months later, the new-elected president Soesilo Bambang Yudhoyono, continued this commitment by establishing several policies and institutions as well as other initiatives, as can be seen in table 1 .

As illustrated in table 1, since 2005 SBY actively translated his international

Table 1. Timeline of Indonesia's Climate Change Policy 2004-2014

\begin{tabular}{|c|c|c|}
\hline Year & Policy Development & Institutions and other Initiatives \\
\hline 2004 & & Ratifying the Kyoto Protocol by Law No 17 \\
\hline 2005 & & $\begin{array}{l}\text { Establishing Designated National Authority } \\
\text { (DNA)-Clean Development Mechanism (CDM) }\end{array}$ \\
\hline
\end{tabular}

2006 Presidential Decree No 5 on National Energy Policy

2007 Long-term National Development Program (RPJP 2005-2025) by Law No 17

2008 National Development Planning Response to Climate Change ("Yellow Book")

2009 Economic and Fiscal Policy Strategies for Climate Change Mitigation ("Green Paper"); Mid-term National Development Program (RPJMN 2010-2014)

2010 Indonesia Climate Change Sectoral Roadmap (ICCSR)

2011 National Action Plan on Greenhouse Gas (GHGs) by Presidential Decree No 61/2011; Presidential Decree No 71/2011 on GHGs Emission Inventory; and Guideline for Developing Local Action for GHGs reduction; Presidential Instruction No 11 on Moratorium on the Issuance of Permits For Primary Forests and Peatlands

2012 Local Action Plan on Climate Change Establishing REDD + National Strategy

2013 National Action Plan on Climate Change Adaptation; Presidential Instruction No 6 on Moratorium on the Issuance of Permits Hosting Conference of the Parties (COP) 13 in Bali and Resulted Bali Action Plan and Bali Road Map Establishing National Council on Climate Change by President Instruction No 46; Establishing National Energy Council by Presidential Regulation No 26 Law No 32 on Protection and Management of Environment; Establishing Indonesia Climate Change Trust Fund (ICCTF); Hosting World Ocean Conference in Manado

Promotion of Adaptation Section Parallel to Mitigation at the Ministry of Environment; Establishing Indonesia Green Investment Fund (IGIF); Signing Letter of Intent (LoI) between Norway Government and Indonesian Government to support Indonesia reducing $\mathrm{GHG}$ emissions Second National Communication; Establishing REDD + Task Force by Presidential Decree No 25 For Primary Forests and Peatlands

Source: Compilated by the author. 
commitment into several national policies, established institutions, and hosted international conferences related to climate change. Indonesia has put remarkable progress when succesfully hosted COP 13 and launched Bali Action Plan and Bali Road Map. The political will and commitment of SBY Government reached its peak when in September 2009 he promised to reduce greenhouse gas emissions by $26-41 \%$ in $\mathrm{G}-20$ Meeting. Although Indonesia was not obliged to reduce its $\mathrm{GHG}$ emissions, Indonesia does have an interest in playing an active role in global efforts to encounter climate change. ${ }^{5}$ Indonesia was the first among developing countries that officially committed to voluntarily reduce the emissions. In his second term of office since October 2009, SBY even incorporated climate change as one of his priorities in Mid-term National Development Program 2010-2014 and in his "A hundred Days Programme." The 2011 National Action Plan for GHG Emissions was a translation of government's commitment as well as an umbrella for climate change mitigation policy. ${ }^{7}$ Due to its active international diplomacy in environment, SBY achieved some awards such as "Global Home Tree" in 2010, "Champion of the Earth 2014 for Policy Leadership" from United Nations Environment Program (UNEP) in November 2014, and was elected as Council Chair and President of the Global Green

5 State Ministry of Environment, "National Action Plan Addressing Climate Change", November 2007, accessed on 10 June 2020, <http://dp2m.umm. ac.id/files/file/National\%20Action\%20Plan\%20 Addressing\%20Climate\%20Change.pdf $>$

6 Zulkifli Rangkuti, "Ekologi Energi dan Pencegahan Degradasi Lingkungan Hidup Prioritas Diplomasi Luar Negeri Indonesia", Jurnal Diplomasi, Vo 1 No.3, Desember 2009, p. 88 in G. Wuryandari, Politik Luar Negeri dan Lingkungan Hidup (Jakarta: LIPI Press, 2012), 226.

7 F. Ardiansyah, N. Gunningham, P. Drahos, "Climate Change and Energy Security Post-Cancun”, pp. 55-80.
Growth Institute. This has enhanced the image and credibility of Indonesia in global environmental commitment.

However, these global achievements were contradicted with his domestic commitment. The government on the contrary issued policies which inconsistent with climate change mitigation. For example, the development of two coal fired power stations by Memorandum of Understanding (MoU) with China worth as US\$ 1,5 billion. According to Gunningham, this inconsistency is due to energy trilemma between energy security, energy poverty, and climate change mitigation. ${ }^{8}$ As explained by Gunningham, Indonesia actually has wealthy energy resources, such as oil, natural gas, and coal. But since oil has been sold with long-term contract, Indonesia is now being an importer of oil since 2006. The same thing might be happened to natural gas since it has also been sold by the longterm contract. At the same time, Indonesia still faced lack access of electricity which at the end pushed the government to rely on coal that still remain plentiful, to fulfill the increasing energy demands. As the fourth largest population in the world, it is not envitable that in the future Indonesia will primarilly depend on coal based energy.

The new presidency under Jokowi in 2014 continued to prioritise environment especially related to climate change impacts. Jokowi incorporated his commitment towards climate change in Mid-term National Development Program (RPJMN 2015-2019): "enhancing the quality of environment, disaster mitigation, and climate change." 9 There are two major

8 N. Gunningham, "Managing the energy trilemma: The case of Indonesia", Energy Policy, vol. 54, 2013, pp. 184-93.

9 National Development and Planning Ministry, Buku I Agenda Pembangunan Nasional (Jakarta: National Development and Planning Ministry, 2015). 
institutional changes that happened in the early of his leadership. First, merger of Ministry of Environment with Ministry of Forestry by arguing that there are many environmental problems in the forestry sector as well as emphasizing that forestry is always seen in exploitative point of view, not in conservation function. Second, dissolve of National Committee on Climate Change and Management Agency on REDD. This has led into pro and cons. Some people argue that this dissolution will hamper efforts to achieve the reduction target since there is no agent that will monitor the implementation of the moratorium, formerly under Management Agency on REDD. ${ }^{10}$ Conversely, some others welcome the policy for the sake of efficiency since there was a pre-existing similar institution which deal with climate change in Ministry of Environment since 1992, namely National Commission on Climate Change. ${ }^{11}$

Although this study does not aimed to compare between SBY's presidency and Jokowi, the continuity or discontinuity of climate change policy since 2004 can not be separated by the policy style of these leaders. As argued by Santikajaya, Jokowi is not as internationalist as SBY and prefers bottom-up foreign policymaking. ${ }^{12}$ Jong added that Jokowi seems to focus mostly on domestic issues. ${ }^{13}$ Therefore, according to Coca, many environmental NGOs and activists supported Jokowi in the election as a new hope to have greener

10 N. Jong, "Concerns loom over Jokowi's climate change resolve", The Jakarta Post, 2 February 2015.

11 G. Wuryandari, Politik Luar Negeri dan Lingkungan Hidup, 141.

12 A. Santikajaya, "Indonesia: Foreign Policy Under Jokowi and Prabowo", The Diplomat, 2014, <http:// thediplomat.com/2014/06/indonesia-foreign-policyunder-jokowi-and-prabowo/>, accessed on 6 June 2020.

13 N. Jong, "Concerns loom." policies and independent policies towards developed countries's interests. ${ }^{14}$ However, the commitment of Jokowi to increase the economic growth has raised some doubts whether he will commit to continue SBY's commitment or not. Jokowi's policy of setting coal mining sector as one of national economic revenue has reaped criticisms, especially from ENGOs. While at the same time Jokowi did not make an improvement of the forest moratorium policy in May 2015, just a renewal as did by SBY every two years since 2011. Another part of this essay will explain more about development of this moratorium policy.

\section{Assessing the Context of Multi-level Governance in Climate Change Policy in Indonesia}

Nation states do not act in a vacuum, therefore, the impact of international, local government, and non-governmental actors in environmental policy, should be considered in assesing climate change policy. They called this the context of multi-level governance. ${ }^{15}$ Furthermore, in assessing the policy response of a state, different political structures, culture and policy styles, and the commitment of political leaders should be considered. According to Connely and Smith, different political structure will determine the opportunity for environmental groups to access or coordinate effectively environmental policy with government. Again, different cultures display different attitudes to different environmental issues.

14 N. Coca, "Will Indonesia Get Serious on Carbon?," The Diplomat, 2015, < http://thediplomat. com/2015/01/will-jokowi-get-serious-on-carbon/>, accessed on 6 June 2020.

15 J. Connelly, G. Smith, D. Benson, C. Saunders, Politics and the Environment From Theory To Practice (London: Routledge, 2012), 246-249. 
The increasing number of international environment agreements creates a framework within which national environmental policy is formulated. Some of these agreements are legally binding and need national responses. Furthermore, as argued by Connely and Smith, local government and its autonomy need to be seen as agents for environmental change. At the same time, the existence and activities of environmental organizations are also significant, to what extent they can actively influence environmental policy. The impacts of these three actors can be applied in assessing climate change policy in Indonesia, completing the commitment of national leaders factors that explained before.

\section{The Impacts of International Actors}

Generally, Indonesian national policy in climate change adjusts with strategies that developed by UNFCCC, which are mitigation and adaptation. The principle of "equity and common but differentiated responsibilities and respective capabilities" between developed countries and developing countries actually did not required Indonesia to reduce its emissions. But, as argued by Gunningham, there are increasing external pressures on developing countries, such as Indonesia to play a more proactive mitigation role as expected by developed countries. ${ }^{16}$

Various international institutions, such as the International Energy Agency (IEA), the Organization for Economic Cooperation and Development (OECD), and G-20 has also set the norms for developing countries and developed countries to commit to mitigation. For instance, the norm of phasing out and rationalizing over the medium term inefficient fossil fuel subsidies which were

16 N. Gunningham, "Managing the energy trilemma," 186. promoted by $\mathrm{G}-20$ in its meeting in $2009 .{ }^{17}$ In addition, in the same year IEA also set direction to low carbon economy. ${ }^{18}$ The mitigation norms which enforced by global energy governance unavoidably influenced Indonesian commitment in climate change policy. As Gunningham pointed out that Indonesian government's ambitious target of $26-41 \%$ in the 2009 G-20 meeting was substantially forced by IEA, G-20, and UNEP. ${ }^{19}$ Subsequently, the commitment of $\$ 1$ billion by the Norway government, that contained in the 2010 Letter of Intent, was a catalyst to implement REDD + program in Indonesia. ${ }^{20}$ The REDD + program requires developing countries to reduce emissions from forested lands by giving incentives through carbon market mechanism. Consequently, as part of Indonesia's commitment to Norway, the moratorium policy on primary forest and peatland conversion was enacted in 2011.21

17 G20 Information Centre, "Leaders' Statement The Pittsburgh Summit September 24-25 2009", accessed on 6 June 2020, <http://www.g20. utoronto.ca/2009/2009communique0925.html > .

18 IEA, "IEA Ministers Confirm Commitment To Stabilise CO2 Emissions And Ensure Transition To Low-Carbon Economy, Welcome Closer Co-Operation With China, India And Russia", accessed on 6 June 2020, <https://www.iea.org/ news/iea-ministers-confirm-commitment-tostabilise-co2-emissions-and-ensure-transition-tolow-carbon-economy-welcome-closer-co-operationwith-china-india-and-russia $>$.

19 N. Gunningham, "Managing the energy trilemma," 189.

20 Resosudarmo and Abdurohman, "Green Fiscal Policy Strategies in Response to Climate Change in Indonesia”, in A. Mori, P. Ekins, S. Lee, S. Speck, K. Ueta, K (eds), The Green Fiscal Mechanism and Reform for Low Carbon Development East Asia and Europe (London: Routledge, 2014).

21 F. Ardiansyah, N. Gunningham, P. Drahos, "Climate Change and Energy Security Post-Cancun”, pp. 5580. 


\section{Local Government and Decentralization}

The 1998 reform has pushed decentralisation by issuing Regional Autonomy Act No. 22 of 1999 and No 25 of 1999, and was implemented in 2001. According to the Act No 22 of 1999, decentralization means the handing over of government authority to district government (Article 1), encompasses the authority within all government tasks, except for the authority in the field of foreign policy, defense and security, justice, monetary and fiscal, religion, and authority of the other fields (article 7 point 1) which one of them is utilization of natural resources and highly strategic technology, conservation, and national standardization (article 7 point 2). Furthermore, article 10 stated that "district authorities manage national resources available in territory and responsible for maintaining environmental sustainability in accordance with legislation". This article appears to contradict with article 7 point
2 regards to whom parties authorise for granting utilization of natural resources licenses.

However, the issuance of the Forestry Act No 41 a few months later asserted this problem. The Act No 41/1999 mandated the forest tenure by the central government and Ministry of Forestry (article 1). On the other hand, the Ministry of Forestry issued Decree No 05.01/2000 to decentralize the issuance of small-scale forest concession licenses that allow the utilization of timber coming from land clearing. 22

The government's action to replace the regional autonomy law by Act No. 32 of 2004 then changed the focus of decentralization to sectoral decentralization. One of the authority that has to be shared between

22 W. Siswanto, W. Wardojo, "Decentralization of the Forestry Sector: Indonesia's Experience" in CJP. Colfer, D. Capistrano (ed.), Politics of Decentralization: forest, power, and people (London: The Earthscan Forest Library, 2005).

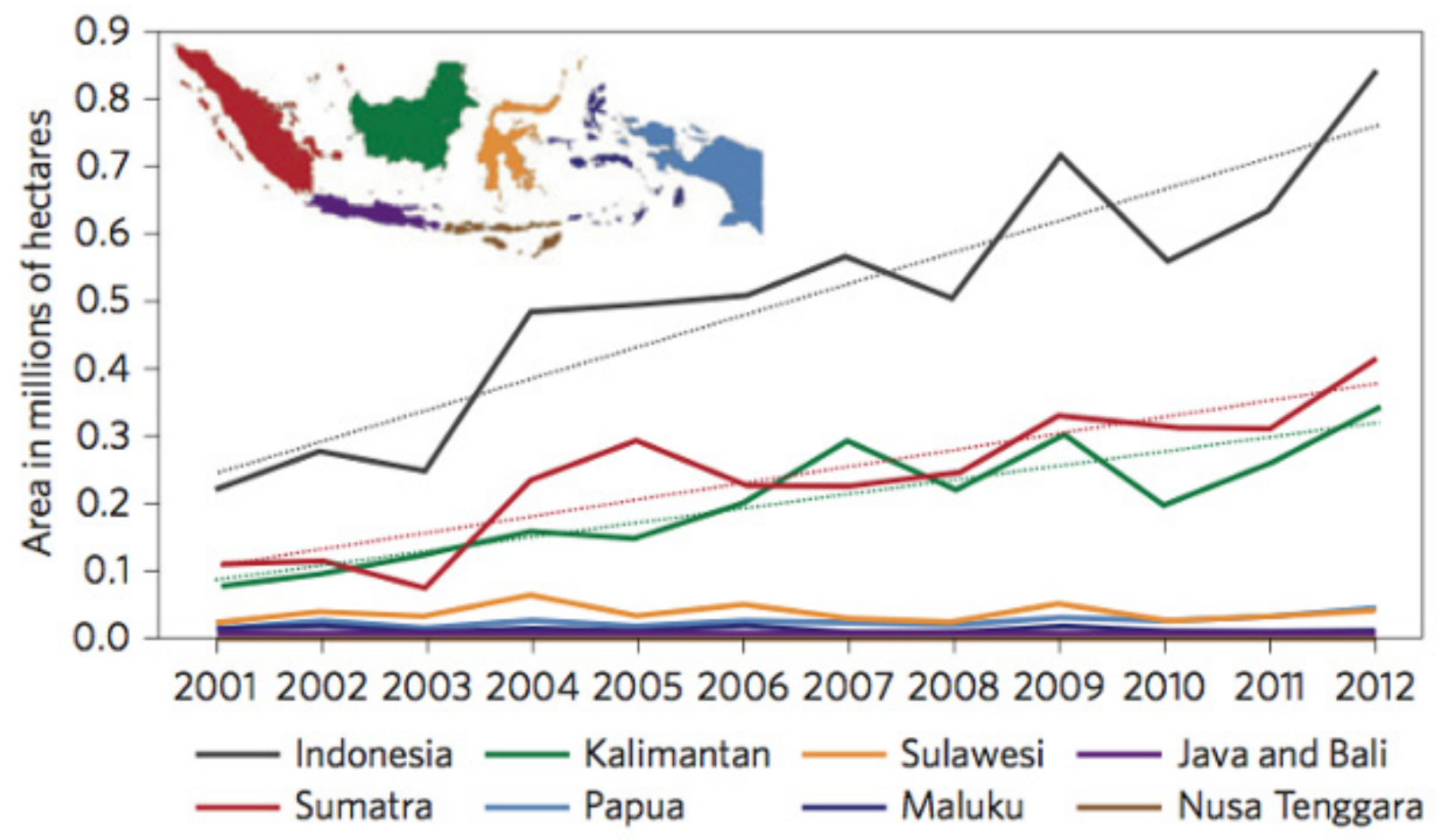

Source: John Vidal, 'Rate of Deforestation in Indonesia Overtakes Brazil, Says Study', 30 June 2014, http://www. theguardian.com/environment/2014/jun/29/rate-of-deforestation-in-indonesia-overtakes-brazil-says-study

Figure 1. The Deforestation Rate in Indonesia 2001-2012 
central and district government is forestry. ${ }^{23}$ However, the vagueness of tasks of each government level has created disagreement between central and district governments whether forest product utilization should be approved by forestry minister or district government. ${ }^{24}$ Since the recommendations from the head of district are now required to issue the licenses from ministry of forestry, both of them have authority in this field. These uncertainty and inconsistency have triggered uncontrolled number of licenses and led to rapid deforestation since 2002 (Figure 1).

In May 2011, the Indonesia government then issued the Presidential Instruction No 10 of 2011 which suspended district governments from granting new concession licenses for primary forests and peatlands in conservation forest, protection forest, production forest and other uses of land, and will be renewed every two years. However, the moratorium is not effectively solving the problem of deforestation, because the Government Regulation No. 24 of 2010 is still on place. This regulation has enabled new licenses continually to be issued during the moratorium period imposed for industrial plants, forest license for the mine, and the release of forest land for plantations. ${ }^{25}$ She added that moratorium area decrease from year to year since there is opportunity to revise the Indicative Map of Deferment Granting Licenses (PIPIB) on natural forests and peat lands every six months.

As illustrated in figure 1 , there is an upward trend of deforestation in Indonesia

23 M. Cabello, M. Farhat, Growth in Indonesia: is it sustainable? The Political Economy of Deforestation (Oxford: Oxford Policy Management, 2013), 14-15.

24 W. Siswanto, W. Wardojo, 2005, "Decentralization of the Forestry Sector."

25 K. Khalid, "Jokowi and Moratorium", Jakarta, WALHI, 2015. even after the 2011 moratorium. It is in line with the fact that the biggest source of emissions in Indonesia comes from land use change and forestry (47\%), while energy sector counted of $20 \%$ and peat fire of $13 \% .^{26}$

\section{The impacts of Environmental Non- Government Organization (ENGO)}

The partnership between government agencies and non-governmental organizations in dealing with climate change impacts have been acknowledged in the 2011 Second National Communication. The existence of NGOs has significantly developed after the reform era. As argued by Wuryandari, they are not always criticizing the government's policies, but are helping to socialize the government's program. ${ }^{27}$ Furthermore, the National Council of Climate Change opened the opportunity for representative of $\mathrm{NGO}$ to involve in this council. One of them is Agus Purnomo, the former Executive Director of World Wildlife Fund (WWF) Indonesia.

Indonesia has a large number of ENGO, both international and national-local organizations. The WWF and Greenpeace are part of international ENGOs that have long operated in Indonesia. In the national level, WALHI (Wahana Lingkungan Hidup Indonesia/Indonesian Forum for the Environment) is the oldest and largest ENGO in Indonesia which was established in October 1980. WALHI unites more than 479 NGOs and 156 individuals throughout Indonesia, with independent offices and grassroot constituencies located in 27 of the

26 Ministry of Environment Republic of Indonesia, Indonesia Second National Communication Under The United Nations Framework Convention on of Climate Change, Jakarta, 2010, < http://unfccc. int/files/national_reports/non-annex_i_natcom/ submitted_natcom/application/pdf/indonesia_snc. pdf $>$, accessed on 4 June 2020.

27 G. Wuryandari, Politik Luar Negeri Indonesia, 29. 
nation's 31 provinces.$^{28}$ WALHI actively take on significant and strategic roles in fighting for the right to the environment and people's livelihoods. During the presidential election, Jokowi visited WALHI office and discussed the management of natural resources and environment. In his visit, May 2014, Jokowi asserted his promise to solve various environmental key problems and natural resources, including a promise of strengthening the environmental institution in Indonesia. ${ }^{29}$

Indonesia has also had Indonesia Civil Society Forum on Foreign Policy which actively influence the foreign policy by stating its standing point regards to certain issues. In November 2014, before Jokowi attended the APEC, ASEAN, and G-20 meeting, forum that consists of $14 \mathrm{NGOs}$ including WALHI, submitted its proposals. They asked urgent climate financing policies that protect developing countries by encouraging climate adaptation program. Jokowi was requested to stop conservation projects that only address the needs of developed countries including blue carbon agenda. Finally, they asked Jokowi to evaluate SBY's commitment to reduce $26 \%$ of emission reduction based on the readiness of community to adapt with climate change impacts. ${ }^{30}$

28 Friends of the Earth Indonesia, "Friends of the Earth Indonesia/Wahana Lingkungan Hidup Indonesia", $<$ http://www.foei.org/member-groups/asia-pacific/ indonesia $>$, accessed on 6 June 2020.

29 A. Tarigan, 'Pidato Direktur Eksekutif Nasional WALHI Dalam Konferensi Nasional Lingkungan Hidup dan SDA', Walhi, Jakarta, 2014.

30 Indonesia Civil Society Forum on Foreign Policy 2014, "Usulan Agenda Politik Luar Negeri Presiden Joko Widodo Dalam Pertemuan APEC, ASEAN, dan G20", WALHI, Jakarta, <https:// igj.or.id/siaran-pers-forum-masyarakat-sipil-untukkebijakan-luar-negeri-untuk-merespon-kehadiranjokowi-dalam-tiga-pertemuan-internasional/>, accessed on 10 June 2020.

\section{Evaluating Climate Change Policy in Indonesia}

After ten years of ratification of the Kyoto Protocol, Indonesia has not yet achieved significant result of climate change mitigation and adaptation. In climate change mitigation, the government's regulatory approach, especially regards to energy policy (Presidential Regulation No. 5 of 2006) as well as deforestation and land use changes (Presidential Instruction No. 10 of 2011), experienced inconsistency in implementation. Instead of getting better, the rate of deforestation (figure 1) and coalbased emissions are even getting higher as its consumption rate doubled from 2000 to $2010 . .^{31}$

Similarly, decentralization approach has not been an effective way in climate change policy. Decentralization even has increased the power of local elites, especially in environmental management. Indrarto et al. stated that there was misinterpretation of autonomy by local governments in which they tend to think that there were no hierarchical linkages between levels of government. ${ }^{32}$ Consequently, conflicting regulations between local and higher-level of regulations are inevitable. On behalf of developing local economic activities, the local authorities can issue small logging licenses to private enterprises as their most important sources of revenues. ${ }^{33}$ In addition, overlapping regulations and lack of law enforcement have made the situation worse. For example, regards to the ineffectiveness of the moratorium policy

31 GB, Indrarto, P, Murharjanti, J, Khatarina, I, Pulungan, F, Ivalerina, J, Rahman, MN, Prana, IAP, Resosudarmo, E, Muharom, "The Context of REDD+ in Indonesia Drivers, Agents and Institutions", Working Paper 92 (Bogor, Indonesia: CIFOR, 2012).

32 GB, Indrarto, et.al, "The Context of REDD+".

33 M. Cabello, M, Farhat, Growth in Indonesia, 12. 
as explained before, various ways are done to remove an area of the moratorium map conducted by the district head, ${ }^{34}$ which at the end lead to rent-seeking behaviour and corruption among district governments, and no sanctions cannot be imposed by Minister of Forestry. ${ }^{35}$ In addition, Indrarto et al. also revealed that the direct election that has been held in Indonesia since 2004, especially for district government, has affected deforestation rate in some areas. ${ }^{36}$ The need for campaign funding and popularity made the district government are trapped in short-term orientation.

The problems of inconsistent regulations and decentralization have challenged the implementation of REDD + as a mechanism under market-based instrument. Indonesia cannot effectively achieve the carbon target as required by REDD+ scheme due to unsupportive domestic conditions. There are some explanations of the government's inconsistency. First, economic reason as a rapidly developing country in which Indonesia certainly needs economic growth, while at the same time has to bear the environmental consequences. ${ }^{37}$ National leadership is built on the promise of improving economic growth which in turn is the measurement of its success. In addition, the structure of Indonesian economy continually dependent on the extraction of natural resources, such as forestry, mining, and agriculture, which most of them located in forests. ${ }^{38}$ Consequently, the rate of land change is gettting higher and is widely enabled. For example, increasing global demand in renewable energy, such as biofuel, has encouraged the growing

34 K, Khalid, "Jokowi and Moratorium".

35 GB, Indrarto, et al., "The Context of REDD+".

36 GB, Indrarto, et al., "The Context of REDD+".

37 F. Ardiansyah, N. Gunningham, P. Drahos, "Climate Change and Energy Security Post-Cancun”, pp. 5580.

38 GB, Indrarto, et al., "The Context of REDD+". crude palm oil (CPO) estates expansion. As a result, forest land conversion into palm oil plantation is continually increasing, especially after 2006 when government issued Presidential Decree No. 5 of 2006 on National Energy Policy and Presidential Instruction No. 1 of 2006 on provision and use of biofuels as alternative energy. To meet the 2015 national target, the government even expands the oil palm estates to Papua. The Ministry of Agriculture and Ministry of Forestry then issued regulations to support this expansion, which the latter even provided up to 100,000 ha and 200,000 ha in Papua for oil palm companies to own estates legally. ${ }^{39}$

Mining is another dominant cause of forest land change in Indonesia. Law No. 4 of 2009 on mineral and coal mining has given the authority to local governments to grant mining license (article 26). The government regulation that comes one year later has enabled new forest licenses to be issued for the mine, even during the moratorium period. Both palm oil plantations and mining contitute the two biggest of land use change in Indonesia. For the sake of economic growth, it is inevitable that the rate of deforestation will continually increase. Even though the government has announced the moratorium policy and has been renewed by Jokowi in May 2015 for the second time since 2011, but it will not result significantly since the companies that has already had lease-use permits can extent their activities (Presidential Instruction No. 10 of 2011 point 2). Whereas the Law No. 18 of 2004 on State Crops, for example, has allowed 35-year land use permit for estate crops to attract investments from overseas. ${ }^{40}$ As advocated by ENGOs, the most important matter for moratorium policy is not only

39 GB, Indrarto, et al., "The Context of REDD +".

40 GB, Indrarto, et al., "The Context of REDD+". 
extention of forest conversion moratorium, but strengthening the substance of moratorium itself. According to Khalid, the weakness of this moratorium policy is since there is lack of law enforcement for violations of new licenses issuance during the moratorium period. ${ }^{41}$

Second, the lack of sectoral coordination between actors in environmental policies. Since performance of bureaucracy is measured by the achievement of sector-based targets the ministries tend to focus on sectoral objectives. Even though officially there is cross-sectoral coordination, but since there is no sectoral links in budget, coordination itself is being another problem. In implementing $\mathrm{REDD}+$, for instance, forest management is under Ministry of Forestry, but the drivers of deforestation are often linked to Ministry of Agriculture, Ministry of Mining and Energy, Ministry of Trade, and Ministry of Finance. ${ }^{42}$ Each of institutions each their own interest, and often contradicts each other. Therefore, cross-sectoral coordination is difficult to be achieved.

The same explanation might be applied in addressing the policy of reducing emissions from fossil fuels and developing alternative source of energy. Inconsistency of regulations happened due to the dilemma between intention to develop renewable energy sources and the domestic demand of providing low-cost source of energy to industry and households. Although Gunningham called it as energy trilemma, but the idea is almost the same that the need to increase economic growth from energy sector and to fulfill the energy needs, especially electricity and fuels, has made the government leave behind the commitment of climate change mitigation. ${ }^{43}$

41 K, Khalid, "Jokowi dan Moratorium".

42 GB, Indrarto, et al., "The Context of REDD+".

43 N, Gunningham, "Managing the energy trilemma."
For Indonesia, there is no single effective approach to deal with climate change impacts, but the combination of these three approaches could be effective ways to improve the state capacity in dealing with climate change policy. Law enforcement and a clear mandate between central and local government should be the most important action to be taken in regards to regulatory approach as well as decentralization approach. However, while Indonesia is still struggling to fix its domestic problems, Indonesia could exploit beneficial mechanisms with international community, especially transfer of technology and funding for developing alternative source of energy, such as geothermal, and climate change adaptation strategy, which actually is more needed by Indonesia. The economic growth is a necessity for a developing country such as Indonesia, but the extent to which developed countries could take responsibilities to "help" the developing countries in securing the environment is still a big question. In this structure, maybe it is difficult for developing countries to get benefit from carbon trading since they still face lack of state capacity in dealing with climate change. The implementation case of Indonesian commitment under Yudhoyono presidency in 2009 G-20 meeting shows us how multi-level governance has influenced the Indonesian government strategy in dealing with climate change policy.

\section{Assessing Indonesian Commitment in 2009: Actors and Motivation}

The announcement of the former Indonesian President, Susilo Bambang Yudhoyono, of a 26-41 percent emission reduction target in 2009 has sparked various reactions and impacts. At the international level, for his promising commitment, Yudhoyono received high 
appreciation as well as international reputation as a visionary leader. ${ }^{44}$ In his speech in Pittsburgh, Yudhoyono showed his personal commitment not only for national development, but also on behalf of the developing countries.

"specifically I would like to convey the aspirations of the developing and underdeveloped world... The developing nations are facing a very difficult situation because we are still a long way off from the degree of prosperity that we see in developed countries such as, poverty, unemployment, disease and hunger. ${ }^{45}$

His promises not only captured world attention, but also consequently has changed the rule of game in which the responsibility to cut the emissions is not only applied for developed countries, but now for both developed and developing countries. ${ }^{46}$

However, a contrast reaction came from domestic public. As argued by Anderson et al., many of them considered Yudhoyono's policy was unrealistic in which the targeting of 26-41 percent was never methodologically explained before. ${ }^{47}$ There was no clear explanation of what Yudhoyono's consideration was at that time. But, the interview with the officials of Ministry of Forestry seemed to confirm this anxiety by

44 P. Anderson, A. Firdaus, and A. Mahaningtyas, "Big Commitments, Small Results: Environmental Governance and Climate Change Mitigation under Yudhoyono in E. Aspinall, M. Mietzner, \& D. Tomsa (Eds.), The Yudhoyono Presidency: Indonesia's Decade of Stability and Stagnation, Singapore: ISEASYusof Ishak Institute, 2015, pp. 258-278.

45 H.E. DR. Susilo Bambang Yudhoyono, "Intervention by President of the Republic of Indonesia on Climate Change at the G-20 Leaders Summit 25 September 2009, Pittsburgh", accessed on 10 June 2020, <http://www.redd-monitor.org/wp-content/ uploads/2013/10/2009-09-25-Intervention-byPresident-SBY-on-Climate-Change-at-the-G-20Leaders-Summit.pdf $>$

46 P. Anderson, A. Firdaus, and A. Mahaningtyas, "Big Commitments, Small Results."

47 P. Anderson, A. Firdaus, and A. Mahaningtyas, "Big Commitments, Small Results." saying that the President only wanted to have a target that was one percent higher than Japan's commitment which has been announced two weeks before the Pittsburgh meeting. ${ }^{48}$

The public anxiety was reasonable. Yudhoyono's commitment in 2009 was announced approaching the end of his first tenure since 2004. In fact, before these stunning promises, Yudhoyono has not taken any personal interest in environmental issues. ${ }^{49}$ Although in 2007 Indonesia was a host of the Conference of the Parties (COP) 13 in Bali, there was no clear explanation of what motivated Indonesia taking this initiative instead of the motivation to leave its footprint in climate change regime negotiation..$^{50}$ The State Ministry of Environment Indonesia only revealed that Indonesia does have an interest in playing an active role in global efforts to encounter climate change. ${ }^{51}$ Besides, despite of the fact that the National Board on Climate Change was established in 2008, according to Muhajir (2010), it did not receive any budget until 2010. The former was evident in the lack of climate change consideration in Indonesian diplomacy during this conference, especially in regards to the idea of Reducing Emissions from Deforestation and Degradation (REDD) as an alternative mechanism for the post-2012 Kyoto Protocol negotiation.

48 P. Anderson, A. Firdaus, and A. Mahaningtyas, "Big Commitments, Small Results."

49 P. Anderson, A. Firdaus, and A. Mahaningtyas, "Big Commitments, Small Results."

50 B. Wardoyo, "Mandat Bali: "Footprint on the Sand", Global $\mathcal{E}$ Strategis, Vol. II, No. 1, 2008, p. 38-55.

51 State Ministry of Environment, "National Action Plan Addressing Climate Change", 2007, <http:// dp2m.umm.ac.id/files/file/National\%20Action\%20 Plan\%20Addressing\%20Climate\%20Change.pdf $>$, accessed on 10 June 2020. 
To put it differently, non-environmental or political factors have been the key determinant of Indonesian diplomacy at that time. The Bali Conference which successfully launched a Bali Road Map that included REDD as its key element, confirmed this view. Indonesia as a host persisted to include REDD in Bali Mandate although this idea was still problematic either for developing countries and in the national level. The developing countries which joined in the G77 and China, have a slightly different view with Indonesia in the extent to which the REDD mechanism should be a key mechanism or only an additional mechanism for post-2012. Brazil, for instance, reminded that REDD should not be linked to the post Kyoto Protocol and therefore, it did not eliminate the obligation of the Annex-1 countries to bear the main task of cutting the green house gas emissions. ${ }^{52}$ For different reasons, Gabon, on behalf of Congo Basin countries, stated that "REDD currently does not protect countries and regions with low deforestation rates from deforestation." 53

In the national level, the REDD issue was also problematic. According to Wardoyo, the lack of a well-established policy as a guidance to adopt the REDD scheme and the lack of internal consensus between actors, including the government and non-government actors, were the main issues around this adoption. ${ }^{54}$ In government sectors, at least there are four ministries related to REDD, which are the Ministry of Forestry, Ministry of Environment, Ministry of Foreign Affairs, and Ministry of Finance. However, conflicts of interests between

52 Third World Network, Bali News Update and Climate Briefings, Malaysia: Third World Network, 2008, <https://www.twn.my/title2/climate/fullpdf/ balifullinclcover.pdf $>$, accessed on 10 June 2020.

53 Third World Network, Bali News Update.

54 B. Wardoyo, "Mandat Bali". these ministries were quite strong in regards to REDD. ${ }^{5}$ The Ministry of Foreign Affairs, for example, alluded to the importance of climate change negotiation on an international level, including Indonesian position as a host of COP 13 in the 2009 Government's Action Plan, just two years after the conference..$^{56}$

Regardless, the REDD mechanism eventually remained, inserted as a key mechanism in the Bali Road Map 2007. Indonesia, for this reason, has succeeded leaving a footprint in climate change regime by being in the frontline of a key global issue..$^{57}$ The success of being a host for COP 13 then inspired Yudhoyono to play a greater role in climate change negotiation. ${ }^{58}$ Yudhoyono's speech in Pittsburgh seemed to resolve the disagreements between Indonesia and other G77 and China on REDD scheme:

"...Many ask how can we spend the limited resources that we have on climate change, which in their eyes are caused by pollutions generated in industrial countries from decades ago and should therefore be their responsibility. Even though in these countries, there's growing climate awareness, we still have a glaring deficit of resources to find the solutions. That is why sometimes we have to set aside our pride, because developing countries do need assistance from developed countries and international agencies are needed, be they in terms of financing, technology, capacity building and cooperation, as indicated in the Bali Road Map."

Furthermore, Yudhoyono persuaded the developing countries to advance their commitments and reminded that reducing

55 B. Wardoyo, "Mandat Bali".

56 M. Muhajir, REDD di Indonesia Kemana Akan Melangkah? (Jakarta: Hu-Ma, 2010).

57 F, Jotzo, "Reaching for the Sky?", Inside Indonesia, 2011, < http://www.insideindonesia.org/reachingfor-the-sky>, accessed on 12 June 2020.

58 B. Wardoyo, "Mandat Bali". 
emissions is also part of developing countries' responsibilities:

"We have to move forward based on the principle of "common but differentiated responsibilities and respective capabilities". Both developed and developing nations must do more and do away with "business as usual" mentality. Developed nations must take the lead, but developing nations must also seriously do their part." 59

Yudhoyono's breakthrough in this meeting has paved the way for a new direction in climate change negotiation. At the Copenhagen Climate Change Conference, December 2009, developing countries such as Brazil, South Korea, Mexico, and South Africa pledged to reduce their emissions relative to business as usual scheme by 30 percent or more. China and India also made pledges to reduce their emissions intensity based on national economic output. ${ }^{60}$

While not dismissing the climate change threat consideration, we can not deny the political economic arguments regarding Yudhoyono's motivation on this commitment. Firstly, gaining direct economic benefit from climate change investment from developed countries is the main economic consideration of Yudhoyono's commitment. Undeniably, the target of $41 \%$ by international support is all about money ${ }^{61}$ In May 2010, the Norway Government and Indonesian Government signed the Letter of Intent (LoI) contained a commitment of $\$ 1$ billion by Norway to support Indonesia reducing greenhouse gas (GHG) emissions. It has been a catalyst to implement REDD + program in Indonesia. ${ }^{62}$ However, according to Norad, by mid-2014

59 H.E. Susilo Bambang Yudhoyono, "Intervention by President".

60 F. Jotzo, "Reaching the Sky".

61 F. Jotzo, "Reaching the Sky".

62 A. Mori, P. Ekins, S. Lee, S. Speck, K. Ueta (eds), The Green Fiscal Mechanism and Reform for Low Carbon Development East Asia and Europe (London: Routledge, 2014). only less than $2 \%$ had been disbursed by Norway. ${ }^{63}$

Secondly, Yudhoyono fully awared the importance of G20 as a global forum, therefore, it has politically driven him to play a greater role and to gain a greater bargaining position for Indonesia in this negotiation. ${ }^{64}$ Undeniably, climate change has been a medium to pursue international prestige. As argued by Anderson et al., a desire to polish the international image of himself and his government has driven Yudhoyono to take this commitment. ${ }^{65}$ As an internationalist in his foreign policy, ${ }^{66}$ international reputation is very important for Yudhoyono. The President took a strong interest and role in foreign policy during Yudhoyono, and therefore Indonesia became an active player in regional and global affairs. ${ }^{67} \mathrm{His}$ foreign policy slogan "thousand friends, zero enemies", was also applied in climate talks, and therefore made the government agreed to every major proposal during the REDD+ negotiations. ${ }^{68}$ Unsurprisingly, due to his active international diplomacy in environment, Yudhoyono achieved some awards such as "Global Home Tree" in 2010, "Champion of the Earth 2014 for Policy Leadership" from United Nations Environment Program (UNEP) in November 2014, and was elected as a recent Council Chair and President of the Global Green Growth Institute.

Similarly, international prestige as one of the determinant factors in environmental policy is also experienced in countries such

63 Norad in Anderson et.al., op.cit.

64 M. Muhajir, REDD di Indonesia.

65 P. Anderson, A. Firdaus, and A. Mahaningtyas, "Big Commitments, Small Results."

66 A. Santikajaya, "Indonesia: Foreign Policy".

67 A. Reid, Indonesia Rising: The Repositioning of Asia's Third Giant (Jakarta: Institute of Southeast Asia Studies, 2012).

68 P. Anderson, A. Firdaus, and A. Mahaningtyas, "Big Commitments, Small Results." 
as Singapore, China, Japan, and Canada. Wardoyo's research in those countries showed that the key determinant of climate change policy is not a pro-environment consideration as expected, but it is international political economy consideration. ${ }^{69}$ Although the motives of these countries vary, but protecting international image is the main reason. The variation between them is just related to the political process or politicization of issue in domestic level. In authoritarian political system, such as in Singapore and China, state is the dominant actor that determines the political economy in climate change policy, together with business group. Conversely, in a more open political system, such as in Japan and Canada, the debate on politicization of issue is quite strong, but eventually it leads to the alignments on the course of national economy. Consequently, the ratification of climate change convention in both countries was not offset by planned regulations in dealing with this issue.

Of Course, Yudhoyono had a strong vision on the emission target, but as argued by Jotzo, the difficulty is coming up from how to implement it, especially when the commitment to REDD is mainly about nonenvironmental or political factors. ${ }^{70}$ These factors, for some cases, have made the government reluctantly pushes for further commitment in the national level. In the end, the international commitment does not mean anything for domestic improvement.

69 B. Wardoyo, "Mandat Bali".

70 F. Jotzo, "Reaching the Sky".

\section{The National Commitment Left Behind}

"Will such emissions stay roughly the same over time? Or will they fall as forests are running out and as fire management improves?

Or could they increase as rising resource prices make forest conversion ever more profitable?"

(Jotzo 2011)

The provoking questions raised by Jotzo essentially revealed an anxiety in regards to the commitment of the Indonesian government to reduce the GHG emissions from deforestation at a national level. There are two important points to his questions, firstly, it is related to forest fire, and secondly, forest conversion. Indeed, they are intertwined and are the main problems of the forestry sector reform which have not resolved yet. The forestry sector reform is needed to make this sector embrace the conservation function, rather than the exploitative one, since there are many environmental problems in the forestry sector.

However, the failure of the Yudhoyono presidency to issue government regulations to support the Law of 32/2009 on Environmental Protection and Management has stopped the reform because without these supporting regulations, the Ministry of Environment cannot implement this law. Meanwhile, this law has ideally addressed the problems of increasing exploitation of natural resources, especially mining and forest conversion. While Yudhoyono in 2011 promised to dedicate the last three years of his term as President to safeguard the environment and forests of Indonesia, ${ }^{71}$ in fact, the deforestation rate in Indonesia has been increasing since 2010, it has even overtaken Brazil.72 Likewise, forest

71 GB, Indrarto, et al., "The Context of REDD+".

72 J. Vidal, "Rate of Deforestation in Indonesia Overtakes Brazil, Says Study", The Guardian, 30 June 2014, accessed on 15 June 2020, <http://www.theguardian. com/environment/2014/jun/29/rate-of-deforestationin-indonesia-overtakes-brazil-says-study> 
fire, especially in tropical rainforests and peatlands, keeps growing, in line with the growth of palm oil plantation in Indonesia. ${ }^{73}$

As promised in 2009, emission reduction is mainly from the forestry sector. However, this sector has not improved. Lack of political will of the Yudhoyono presidency to reform this sector, makes the problem continually happen and it is getting worse by the recent problem of the forest fire in Indonesia in 2015. The forest fire crisis, according to Meijaard, is probably considered as the biggest environmental crime of the 21st century. ${ }^{74}$ It has caused hundreds of people to become ill and some of them died, not to mention the economic impacts caused by the haze.

The increasing growth of palm oil plantation in forests and peatlands is unavoidable due to weak national leadership of the President Yudhoyono in reforming the forestry sector. While in May 2011, the Presidential Instruction was issued to suspend district governments from granting new licenses for primary forests and peatlands (Presidential Instruction No 10/2011), however, the Ministry of Forestry broke the moratorium by changing the scope of area to which the regulation applied. ${ }^{75}$ Unsurprisingly, the moratorium area of primary forests and peatlands is declining year by year. As shown in a 2014 map, it was five million hectares smaller than the area was agreed to be in 2011. Unfortunately, Yudhoyono was unable to act decisively towards this sector.

73 L. Allen, "Is Indonesia's fire crisis connected to the palm oil in our snack food?', The Guardian, 23 October 2015, accessed on 15 June 2020, <http://www.theguardian. $\mathrm{com} / \mathrm{commentisfree} / 2015 /$ oct/23/is-indonesias-firecrisis-connected-palm-oil-in-snack-food $>$.

74 E. Meijaard, "Erik Meijaard: Indonesia's Fire CrisisThe Biggest Environmental Crime of the 21st Century", Jakarta Globe, 23 October 2015.

75 P. Anderson, A. Firdaus, and A. Mahaningtyas, "Big Commitments, Small Results."
For a long time, forestry sector is untouchable. Arguably, it is related to the political economic factors of this sector. As argued by Anderson et al., the Ministry of Forestry is one of the most corrupt institutions in Indonesia and seems to serve for the business interests of forestry industry. ${ }^{76}$ In September 2011, for example, the Ministry of Forestry issued a regulation No 62/2011 that classified oil palm plantations as forestry plantation, and therefore conversion of forests to palm oil plantations would not be considered as deforestation. ${ }^{77}$ Consequently, land change to palm oil plantations keeps going and the moratorium policy did not mean anything. Moreover, the plantation companies cleared the forest by fire, although it is illegal, since the sanction was insignificant and the enforcement was so loose..$^{78}$

In fact, these developments cannot be separated from the ongoing political system in Indonesia after the 1998 reform. The direct elections in the national and district levels, both for legislative and executive bodies, have made them to seek for political funding. Many plantation companies are major political donors. ${ }^{79}$ As a result, corruption in the licensing process was not surprising. In September 2014, for example, the Indonesian Corruption Eradication Commision arrested the governor of Riau province as receiving bribe from oil palm

76 P. Anderson, A. Firdaus, and A. Mahaningtyas, "Big Commitments, Small Results."

77 C. Lang, "President Yudhoyono promises to dedicate the next three years to protecting Indonesia's forests", 28 September 2011, accessed on 20 June 2020, <http://www.redd-monitor.org/2011/09/28/ president-yudhoyono-promises-to-dedicatethe-next-three-years-to-protecting-indonesiasforests/>.

78 P. Anderson, A. Firdaus, and A. Mahaningtyas, "Big Commitments, Small Results."

79 P. Anderson, A. Firdaus, and A. Mahaningtyas, "Big Commitments, Small Results." 
businessman who asked for forest conversion to palm oil plantations. ${ }^{80}$

The forest fire crisis is a great blow for Indonesia's commitment to REDD, especially approaching the climate talks in Paris, December 2015. This crisis will only prove that the stunning commitment of Indonesia in 2009 was not followed by the same spirit in the national level.

\section{Conclusion}

The commitment of government and multi-level governance has influenced the Indonesian government capacity in dealing with climate change policy. The democratic political structure in Indonesia, especially after political reform in 1998 has created a positive circumstances in which environmental issues can be taken into account by national leaders. A greater freedom of civil society has raised the activism of ENGO in Indonesia. But, at the same time, decentralization that followed the 1998 reform has not positively contributed yet to state capacity in dealing with climate change policy. Instead of playing as a agent of environmental change, the local government and its autonomy even caused ineffectiveness of climate change policy implementation.

In a nutshell, none should be in any doubt on the point that Yudhoyono presidency has dealt with climate change issues more seriously than any previous president. However, the context of multilevel governance, namely the international, local government, and non-governmental actors has influenced the implementation of climate change policy in Indonesia. Since Indonesia falls behind on its national commitment, the Yudhoyono presidency's role in establishing climate change regime is more driven by its international stature.

80 R. Henschke, "Ada korupsi di balik kabut asap Indonesia" ('There is Corruption behind Indonesian smog haze'), BBC Indonesia, 17 October 2015.

\section{REFERENCES}

Allen, L., "Is Indonesia's fire crisis connected to the palm oil in our snack food?', The Guardian, 23 October 2015, accessed on 15 June 2020, <http://www.theguardian.

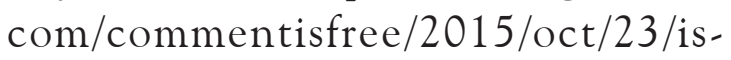
indonesias-fire-crisis-connected-palmoil-in-snack-food $>$.

Anderson, P., Firdaus, A., and Mahaningtyas, A., "Big Commitments, Small Results: Environmental Governance and Climate Change Mitigation under Yudhoyono in E. Aspinall, M. Mietzner, \& D. Tomsa (Eds.), The Yudhoyono Presidency: Indonesia's Decade of Stability and Stagnation, Singapore: ISEAS-Yusof Ishak Institute, 2015, pp. 258-278.

Ardiansyah, F., Gunningham, N., Drahos, P., "Climate Change and Energy Security Post-Cancun: The Indonesia Perspective", in NA, Putra, E. Han, Governments' Responses to Climate Change: Selected Examples From Asia Pacific (Singapore: Springer, 2014), pp. 55-80.

Cabello, M., Farhat, M., Growth in Indonesia: is it sustainable? The Political Economy of Deforestation (Oxford: Oxford Policy Management, 2013), 14-15.

Coca, N., "Will Indonesia Get Serious on Carbon?," The Diplomat, 2015, <http:// thediplomat.com/2015/01/will-jokowiget-serious-on-carbon/ $>$, accessed on 6 June 2020.

Connelly, J., Smith, G., Benson, D., Saunders, C., Politics and the Environment From Theory To Practice (London: Routledge, 2012).

Friends of the Earth Indonesia, "Friends of the Earth Indonesia/Wahana Lingkungan Hidup Indonesia”, accessed on 6 June 2020, <http://www.foei.org/ member-groups/asia-pacific/indonesia $>$ 
G20 Information Centre, “Leaders' Statement The Pittsburgh Summit September 24-25 2009", accessed on 6 June 2020, <http://www.g20.utoronto. ca/2009/2009communique0925.html > .

Gunningham, N., "Managing the energy trilemma: The case of Indonesia", Energy Policy, vol. 54, 2013, pp. 184-93.

Happaerts, S., Bruyninckx, H., "Rising Powers in Global Climate Governance.

Negotiating in the New World Order", Working Paper No. 124, 2013, accessed on 4 June 2020, <https://ghum. kuleuven.be/ggs/publications/working_ papers/new_series/wp121-130/wp124happaerts-bruyninckx-finaal.pdf>

H.E. DR. Susilo Bambang Yudhoyono, "InterventionbyPresidentoftheRepublic of Indonesia on Climate Change at the G-20 Leaders Summit 25 September 2009, Pittsburgh", accessed on 10 June 2020, <http://www.redd-monitor.org/ wp-content/uploads/2013/10/2009-09. 25-Intervention-by-President-SBY-onClimate-Change-at-the-G-20-LeadersSummit.pdf $>$

Henschke, R., "Ada korupsi di balik kabut asap Indonesia" ('There is Corruption behind Indonesian smog haze'), BBC Indonesia, 17 October 2015.

IEA, "IEA Ministers Confirm Commitment To Stabilise CO2 Emissions And Ensure Transition To Low-Carbon Economy, Welcome Closer Co-Operation With China, India And Russia”, accessed on 6 June 2020, <https:/www.iea.org/news/ iea-ministers-confirm-commitmentto-stabilise-co2-emissions-and-ensuretransition-to-low-carbon-economywelcome-closer-co-operation-withchina-india-and-russia $>$.
Indonesia Civil Society Forum on Foreign Policy 2014, "Usulan Agenda Politik Luar Negeri Presiden Joko Widodo Dalam Pertemuan APEC, ASEAN, dan G20", WALHI, Jakarta, accessed on 10 June 2020, <https://igj.or.id/ siaran-pers-forum-masyarakat-sipiluntuk-kebijakan-luar-negeri-untukmerespon-kehadiran-jokowi-dalamtiga-pertemuan-internasional/>

Indrarto, GB., Murharjanti, P., Khatarina, J., Pulungan, I., Ivalerina, F., Rahman, J., Prana, MN., Resosudarmo, IAP., Muharom, E., "The Context of REDD+ in Indonesia Drivers, Agents and Institutions", Working Paper 92 (Bogor, Indonesia: CIFOR, 2012).

Jong, N., "Concerns loom over Jokowi's climate change resolve", The Jakarta Post, 2 February 2015.

Jotzo, F., "Reaching for the Sky?", Inside Indonesia, 2011, accessed on 12 June 2020, < http://www.insideindonesia. org/reaching-for-the-sky $>$.

Khalid, K. "Jokowi and Moratorium", Jakarta, WALHI, 2015.

Lang, C., "President Yudhoyono promises to dedicate the next three years to protecting Indonesia's forests", 28 September 2011, accessed on 20 June 2020, < http://www.redd-monitor. org/2011/09/28/president-yudhoyonopromises-to-dedicate-the-nextthree-years-to-protecting-indonesiasforests/ $>$.

Meijaard, E., "Erik Meijaard: Indonesia's Fire Crisis-The Biggest Environmental Crime of the 21st Century", Jakarta Globe, 23 October 2015. 
Ministry of Environment Republic of Indonesia, Indonesia Second National Communication Under The United Nations Framework Convention on of Climate Change, Jakarta, 2010, accessed on 4 June 2020, <http:// unfccc.int/files/national_reports/nonannex_i_natcom/submitted_natcom/ application/pdf/indonesia_snc.pdf $>$

Mori, A., Ekins, P., Lee, S., Speck, S., Ueta, K. (eds), The Green Fiscal Mechanism and Reform for Low Carbon Development East Asia and Europe (London: Routledge, 2014).

Muhajir, M., REDD di Indonesia Kemana Akan Melangkah? (Jakarta: Hu-Ma, 2010).

National Development and Planning Ministry, Buku I Agenda Pembangunan Nasional (Jakarta: National Development and Planning Ministry, 2015).

Oktaviani, R., Amaliah, S., Ringler, C., Rosegrant, MW., Sulser, TB., "The Impact of Global Climate Change on the Indonesian Economy", IFPRI Discussion Paper 01148, 2011, accessed on 4 June 2020, < http://www.ifpri.org/sites/default/ files/publications/ifpridp01148.pdf>

Reid, A., Indonesia Rising: The Repositioning of Asia's Third Giant (Jakarta: Institute of Southeast Asia Studies, 2012).

Resosudarmo and Abdurohman, "Green Fiscal Policy Strategies in Response to Climate Change in Indonesia", in A. Mori, P. Ekins, S. Lee, S. Speck, K. Ueta, K (eds), The Green Fiscal Mechanism and Reform for Low Carbon Development East Asia and Europe (London: Routledge, 2014).

Santikajaya, A., "Indonesia: Foreign Policy Under Jokowi and Prabowo", The Diplomat, 2014, accessed on 6 June 2020, $<$ http://thediplomat.com/2014/06/ indonesia-foreign-policy-under-jokowiand-prabowo/>.
Siswanto, W., Wardojo, W., "Decentralization of the Forestry Sector: Indonesia's Experience" in CJP. Colfer, D. Capistrano (ed.), Politics of Decentralization: forest, power, and people (London: The Earthscan Forest Library, 2005).

State Ministry of Environment, "National Action Plan Addressing Climate Change", 2007, accessed on 10 June 2020, <http:// dp2m.umm.ac.id/files/file/National\%20 Action\%20Plan\%20Addressing\%20 Climate\%20Change.pdf $>$.

Tarigan, A., 'Pidato Direktur Eksekutif Nasional WALHI Dalam Konferensi Nasional Lingkungan Hidup dan SDA', Walhi, Jakarta, 2014.

Third World Network, Bali News Update and Climate Briefings (Malaysia: Third World Network, 2008), accessed on 10 June $2020<$ https://www.twn.my/title2/ climate/fullpdf/balifullinclcover.pdf $>$.

Vidal, J., "Rate of Deforestation in Indonesia Overtakes Brazil, Says Study", The Guardian, 30 June 2014, accessed on 15 June 2020, <http://www.theguardian. com/environment/2014/jun/29/rate-ofdeforestation-in-indonesia-overtakesbrazil-says-study>

Wardoyo, B., "Mandat Bali: "Footprint on the Sand", Global 8 Strategis, Vol. II, No. 1, 2008, p. 38-55.

World Resources Institute, "Forest and Landscapes in Indonesia", undated, accessed on 4 June 2020, <http:/www.wri.org/ our-work/project/forests-and-landscapesindonesia/climate-change-indonesia $>$

Wuryandari, G., Politik Luar Negeri dan Lingkungan Hidup (Jakarta: LIPI Press, 2012). 